Cerebrovasc Dis 2011;32:614-615

DOI: $10.1159 / 000334578$

\section{Fatal Intracerebral Hemorrhage Associated with Administration of Recombinant Tissue Plasminogen Activator in a Stroke Patient on Treatment with Dabigatran}

\section{Ignacio Casado Naranjo, Juan Carlos Portilla-Cuenca, Pedro Enrique Jiménez Caballero, Maria Luisa Calle Escobar, Raúl Mauricio Romero Sevilla}

Department of Neurology, Stroke Unit, Hospital San Pedro de Alcántara, Cáceres, Spain

Dabigatran is an oral anticoagulant that has been recently approved in Europe for prevention of stroke in patients with nonvalvular atrial fibrillation (NVAF), demonstrated to be equally safe or safer or at least as effective as warfarin [1].

In selected patients, we have the opportunity of thrombolysis treatment within $4.5 \mathrm{~h}$ after onset of ischemic stroke (IS) [2, 3] in order to minimize the risk of bleeding complications. Concomitant use of anticoagulants is a contraindication for administration of recombinant tissue plasminogen activator ( $\mathrm{rtPA}$ ) even if the international normalized ratio is $<1.7$ [4]. There is little information on bleeding risk in patients treated with rtPA while taking dabigatran $[5,6]$.
We report a 62-year-old diabetic man who underwent electric cardioversion for NVAF detected 2 months previously, who refused to take acenocoumarol and who was pretreated only with enoxaparin for 1 month. After the procedure, he was treated with dabigatran $110 \mathrm{mg}$ twice daily, as an off-label situation. Three hours after taking the third dose, he had an abrupt onset of aphasia and right hemiplegia. The National Institutes of Health Stroke Scale score was 18. A non-contrast head computed tomography (CT) scan was normal. Perfusion CT revealed a deficit of $>2 / 3$ of the left middle cerebral artery area (fig. 1a). His blood pressure was 142/78 $\mathrm{mm} \mathrm{Hg}$ and his glycemic level was $233 \mathrm{mg} / \mathrm{dl}$. Coagulation parameters were: platelet count $154 \times 10^{9} / 1$ (normal range 150-450), prothrombin time $14.6 \mathrm{~s}$ (normal range 8-14), international normalized ratio 1.29 (normal range 0.7-1.5), activated partial thromboplastin time $37.1 \mathrm{~s}$ (normal range 24-38) and fibrinogen level $293 \mathrm{mg} / \mathrm{dl}$ (normal range 200-450).

After obtaining informed consent, thrombolysis was initiated at $190 \mathrm{~min}$ from stroke onset. The neurological status did not change. Twelve hours later, the patient became drowsy and fell into a coma shortly thereafter. A CT brain scan showed a lobar hemorrhage with mass effect (fig. 1b). Control coagulation parameters were normal. The patient was intubated and transferred to an intensive care unit where he died 2 days later.

To the best of our knowledge, this is the first report to describe a fatal bleeding complication in a patient treated with dabigatran who had an IS and was treated with intravenous rtPA.
Fig. 1. a Perfusion CT of the brain. b CT scan $12 \mathrm{~h}$ after rtPA perfusion.
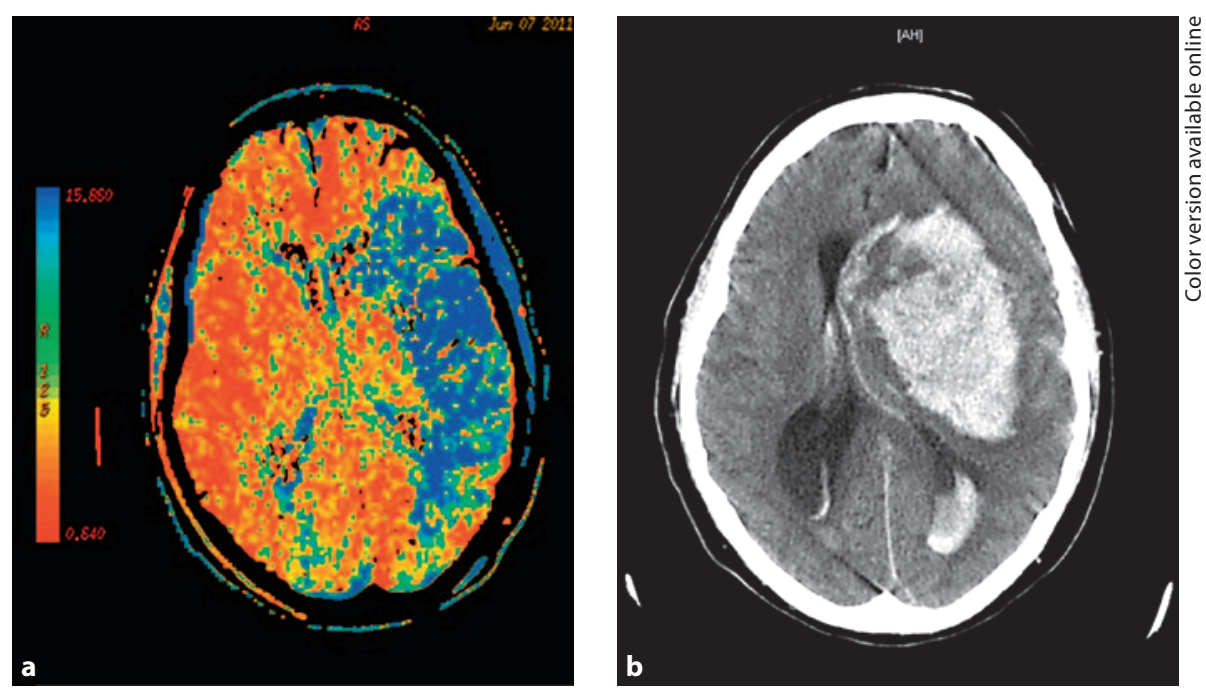

\section{KARGER}

Fax +4161306 1234 E-Mail karger@karger.ch www.karger.com
(อ) 2011 S. Karger AG, Basel

1015-9770/11/0326-0614\$38.00/0 
Table 1. Main clinical characteristics of patients reported

\begin{tabular}{llllllllll}
\hline Study & $\begin{array}{l}\text { Age } \\
\text { years/sex }\end{array}$ & $\begin{array}{l}\text { Dabigatran } \\
\text { dose, } \mathrm{mg}\end{array}$ & $\begin{array}{l}\text { Last dose } \\
\mathrm{h}\end{array}$ & PT, s & aPTT, s & INR & $\begin{array}{c}\text { NIHSS } \\
\text { rtPA time } \\
\text { onset, min }\end{array}$ & Outcome \\
\hline $\begin{array}{l}\text { De Smedt et al. [5] } \\
\text { Matute et al. [6] }\end{array}$ & 46/F & NA & 7 & NA & 34.8 & 1.2 & 19 & just below 270 improvement (12) \\
$\begin{array}{l}\text { Present study } \\
\text { 62/M }\end{array}$ & 220 o.i.d. & 15 & 11.4 & 30.6 & 1 & 4 & $\begin{array}{l}120 \\
\text { asymptomatic (0) } \\
\text { death }\end{array}$ \\
\hline
\end{tabular}

Figures in parentheses are National Institutes of Health Stroke Scale scores.

$\mathrm{PT}=$ Prothrombin time; $\mathrm{aPTT}=$ activated partial thromboplastin time; $\mathrm{INR}=$ international normalized ratio; $\mathrm{NA}=$ not available; o.i.d. = one per day; b.i.d. = twice daily.

After regulatory approval, more patients with NVAF will be treated with dabigatran and some of them will developed an IS, forcing the clinician to decide whether to treat these cases with rtPA or not, or use a lower dose of the drug [7]. Including ours, only 3 diverse cases have been reported so that it is difficult to draw any conclusions (table 1). It is possible that a shorter time interval between the last dabigatran dose and rtPA administration may be a critical factor in the increased risk of bleeding, considering the pharmacological characteristics of the drug.

Secondary intracerebral hemorrhage might have occurred even without rtPA or dabigatran use, due to large perfusion deficit or diabetes [8].

Our case warrants caution when deciding on the administration of rtPA in patients treated with dabigatran who have an IS.

\section{Disclosure Statement}

The authors state that there are no conflicts of interest.

\section{References}

1 Rother J, Crijns H: Prevention of stroke in patients with atrial fibrillation: the role of new antiarrhythmic and antithrombotic drugs. Cerebrovasc Dis 2010;30:314-322.

- 2 Hacke W, Kaste M, Bluhmki E, Brozman M, Davalos A, Guidetti D, Larrue V, Lees KR, Medeghri Z, Machnig T, Schneider D, von Kummer $\mathrm{R}$, Wahlgren N, Toni D: Thrombolysis with alteplase 3 to 4.5 hours after acute ischemic stroke. N Engl J Med 2008;359:1317-1329.
3 Wahlgren N, Ahmed N, Davalos A, Hacke W, Millan M, Muir K, O Roine R, Toni D, Lees KR, SITS investigators: Thrombolysis with alteplase 3-4.5 h after acute ischemic stroke: an observational study. Lancet 2008;372:1303-1309.

4 Prabhakaran S, Rivolta J, Vieira JR, Rincon F, Stillman J, Marshall RS, Chong JY: Symptomatic intracerebral hemorrhage among eligible warfarin-treated patients receiving intravenous tissue plasminogen activator for acute ischemic stroke. Arch Neurol 2010;67:559-563.

5 De Smedt A, De Raedt S, Nieboer K, De Keyser J, Brouns R: Intravenous thrombolysis with recombinant tissue plasminogen activator in a stroke patient treated with dabigatran. Cerebrovasc Dis 2010;30:533534.

6 Matute MC, Guillán M, Garcia-Caldentey J, Buisan J, Aparicio M, MasJuan J, Alonso de Leciñana M: Thrombolysis for acute ischaemic stroke in a patient on treatment with dabigatran. Thromb Haemost 2011;106: 178-179.

7 Dempfle $\mathrm{CH}$, Hennerici MG: Dabigatran and stroke thrombolysis. Cerebrovasc Dis 2010;30:203-205.

-8 Lansberg MG, Albers GW, Wijman CA: Symptomatic intracerebral hemorrhage following thrombolytic therapy for acute ischemic stroke: a review of the risk factors. Cerebrovasc Dis 2007;24:1-10.

Ignacio Casado Naranjo

Department of Neurology

Hospital San Pedro de Alcántara

ES-10001 Cáceres (Spain)

Tel. +34 927256 322, E-Mail icasadon@gmail.com 